\title{
A NEW MASTER PLAN FOR HARRAN UNIVERSITY BASED ON GEODESIGN
}

\author{
F. B. Ernst ${ }^{\text {a }}$, S. Erdoğan ${ }^{\text {a }}$, M. Yılmaz a , M. Ulukavak ${ }^{\text {a }}$, H. İ. Şenol a , A. Memduhoğlu ${ }^{\text {a, }}$ \\ ${ }^{a}$ Harran University, Department of Geomatics Engineering, Osmanbey Campus, 63000 Şanlıurfa, Turkey - (f.b.ernst, \\ serdogan, yilmazmeh, mulukavak, hsenol, akadirm)@ harran.edu.tr
}

KEY WORDS: Master plan, Harran University, Geodesign, GIS

\begin{abstract}
:
Harran hosted the historical Harran University, which is considered to be the oldest university of the world. The Department of Geomatics of the modern Harran University has been charged with the design of a new master plan using Geodesign technology. Carl Steinitz developed a complete framework for doing Geodesign as applied to regional landscape studies. In this project "Geodesign Hub", an online software for collaborative Geodesign, has been selected as the main tool. According to the Geodesign concept, data collection had to be limited to support the evaluation of the ten selected systems. The deployment of Unmanned Aerial Systems (UAS) has been necessary in order to collect data with the required accuracy for such a vast area. Currently, works on the third model of the Geodesign framework are continuing.
\end{abstract}

\section{INTRODUCTION}

Harran, today a small district center in Sanliurfa Province, was founded about 5000 years ago in the cradle of human civilization, the fertile crescent. It hosted the historical Harran University, which is considered to be the oldest university of the world. This city was not just created somewhere by chance and then, just happened to prosper. On the contrary, the selection of this location gives prove that even at that time, man used the concept of Geodesign. During this selection process the following criteria, most probably have been of importance:

1. Geopolitical location: It lied between the superpowers of the West (Greeks, Romans) and the East (Assayers, Persia).

2. Transportation: It lied at the crossroads of two ancient main roads: The West-East axis from the Mediterranean to the plains of the Tigris, and the North-South axis running to inner Anatolia.

3. Center for agriculture: Situated in the middle of Harran Plain with its fertile soils and abundant water support with food was always guaranteed.

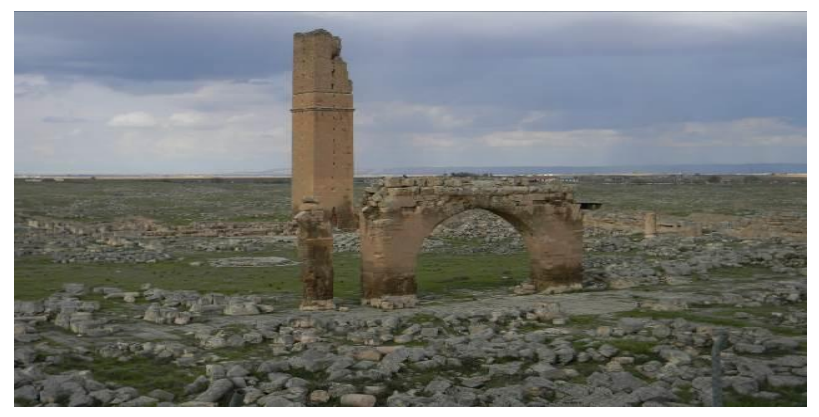

Figure 1. Remnants of ancient Harran University
After the historic Harran University was abandoned about 1500 years ago, the new Harran University was established in the Province center of Sanliurfa in the year 1992. In 1993, its main campus, Osmanbey was created from scratch. Although founded more than 2000 years later than the historic university it remains unclear what the criteria for this selection were. A closer look on the current location of Osmanbey Campus reveals the following signs of improper planning:

1. Being $25 \mathrm{~km}$ located outside the center of Sanliurfa, this relatively long distance will not be bridged by a new development band connecting the two centers. Besides such a connection would mean the occupation of fertile soils.

2. The weak infrastructure of the campus (missing shopping markets, pharmacy, primary and secondary schools, insufficient housing) hinders the development of a separate settlement center.

3. Moderate transportation (no speedy connection to the city center and the management center of the university)

4. Long distance between the campus and the rectorate causes serious management problems (maintenance, cleaning)

However, with an area of 2870 ha Osmanbey Campus has an enormous development potential. As there was already works for a new master plan underway, the Department of Geomatics of Harran University applied for the design of a new master plan using Geodesign technology. This application was approved in spring 2017 and respective funds were granted by the university. A master plan corresponds to a "Nazım İmar Planı" according to the Turkish law and has to be drawn at a scale of 1:2000 or 1:5000 (Yomralioglu, 2014). 


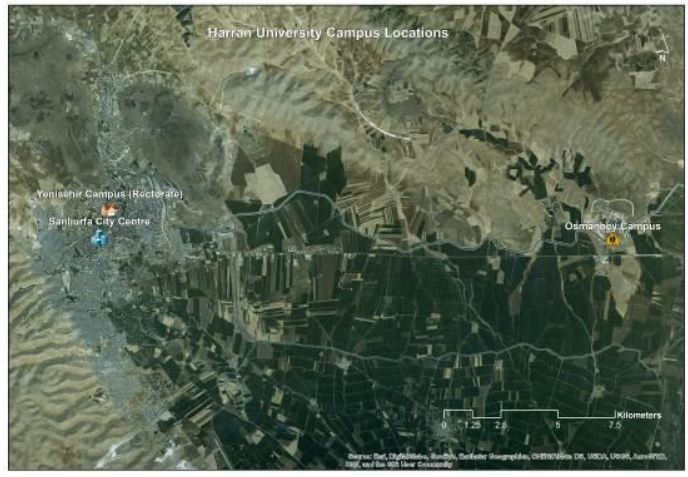

Figure 2. Location of Osmanbey Campus

\section{METHODOLOGY}

While many researchers have dealt with Geodesign in the 20th century, the term has only become popular recently. In 1995, Carl Steinitz who was working with his colleagues and students over a period of approximately 30 years at the Harvard Graduate School of Design developed a complete framework for doing geodesign as applied to regional landscape studies. This framework originally called Framework for Landscape Planning and later renamed to Framework for Geodesign (Steinitz, 2012), advocates the use of six models to describe the overall planning (geodesign) process as shown in figure 3. In "Framework for Geodesign" the author delineates the conceptual framework for doing Geodesign, which is considered to be the standard book for both practitioners and academics.

Every organization, large or small, public or private, does three things: it gets and manages information (data), analyzes or assesses that information with respect to some purpose (analysis), and (based on that information and those assessments) creates or re-creates goods and/or services (design). It is, in fact, the creation or re-creation of goods and/or services that gives most organizations their reason for being. If for this creation GIS is used then actually, we can speak of Geodesign.

In his book "Geodesign - Case Studies in Regional and Urban Planning" McElwaney (McElwaney, 2012) lists seven key characteristics of Geodesign. However, during the ongoing discussions of our project the following three characteristics have been determined as the most important ones:

1. Goedesign provides a fast feedback on your changes to a plan making the impacts of it immediately visible.

2. Geodesign supports a participatory approach giving all stakeholders a voice for the planning of their future.

3. Geodesign uses an intuitive GUI that allows the active participation of a multidisciplinary project team and decision-makers at the same time.

\section{The geodesign framework - by Carl Steinitz}
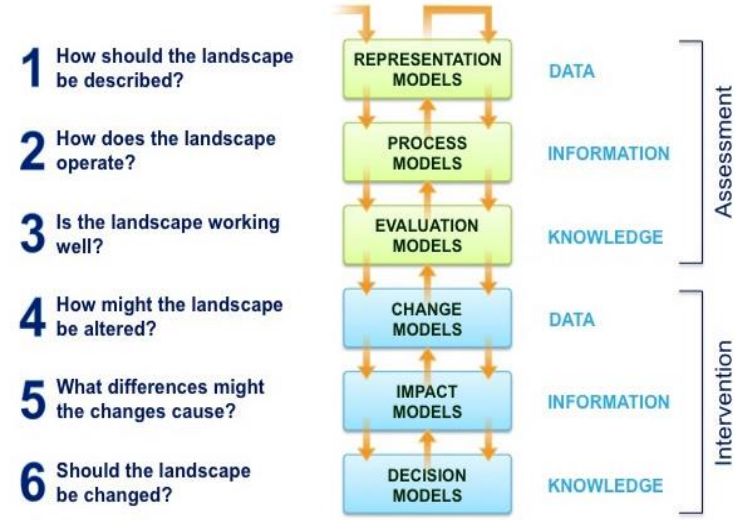

Figure 3. Geodesign framework by Steinitz

\section{CURRENT STATUS}

In many GIS based projects, during the first project phase data collection is the main topic. And very often, big databases consisting of hundreds of layers with outstanding accuracy are created without having a clear idea who and for what they will ever be used for. During the early phases of our project, discussions about all reasons for this study and which methodology would support the finding of reasonable solutions were dominating.

According to the Geodesign methodology developed by Steinitz, a consecutive pass through the six models should be undertaken for three times. The first pass serves the clarification of the reason for this study. Although it seemed obvious that a new master plan was underway anyways so, it should be done properly using a scientific method like e.g. Geodesign. However, during our discussions it became clear that we wanted much more. Especially, the following reasons could be identified:

1. In contrast to old master plans and the one already underway, our master plan would not only deal with the development of the centre of Osmanbey Campus (ca. 150 ha) but the whole area stretching over more than 2800 ha.

2. We wanted a master plan that is worth more than the paper written on it. That meant, only active participation of the decision-makers would give a real chance that the master plan would ever be implemented.

3. Changes always occur. Therefore, we wanted to create not a static document rather, a dynamic system that could accommodate changes if required.

During the second pass according to Steinitz, the exact methodology to be used for a project has to be set up. There is nothing like "the" Geodesign methodology. This has to be found out for each project separately. After testing of different systems, we decided to go with "Geodesign Hub" found by Ballal (Nyerges, 2016). Geodesign Hub is an online software for collaborative geodesign. It enables teams to create and share concepts, to design collaboratively, and to receive change- 
assessments instantly - all in a highly synergetic, efficient and easy to use environment.

The starting point in Geodesign Hub is the set-up of evaluation systems. These systems shall answer the question whether the current study area is working well or not. Up to 10 evaluation systems are allowed. This idea follows the logic that before you can start thinking about change you have to find out how well your systems are working currently. We decided to focus on the following 10 systems:

1. Agriculture

2. Forest, parks and protected areas

3. Roads

4. Education facilities

5. Low-density housing

6. High-density housing

7. Small food processing enterprises

8. Touristic facilities

9. Aquaculture

10. Greenhouses
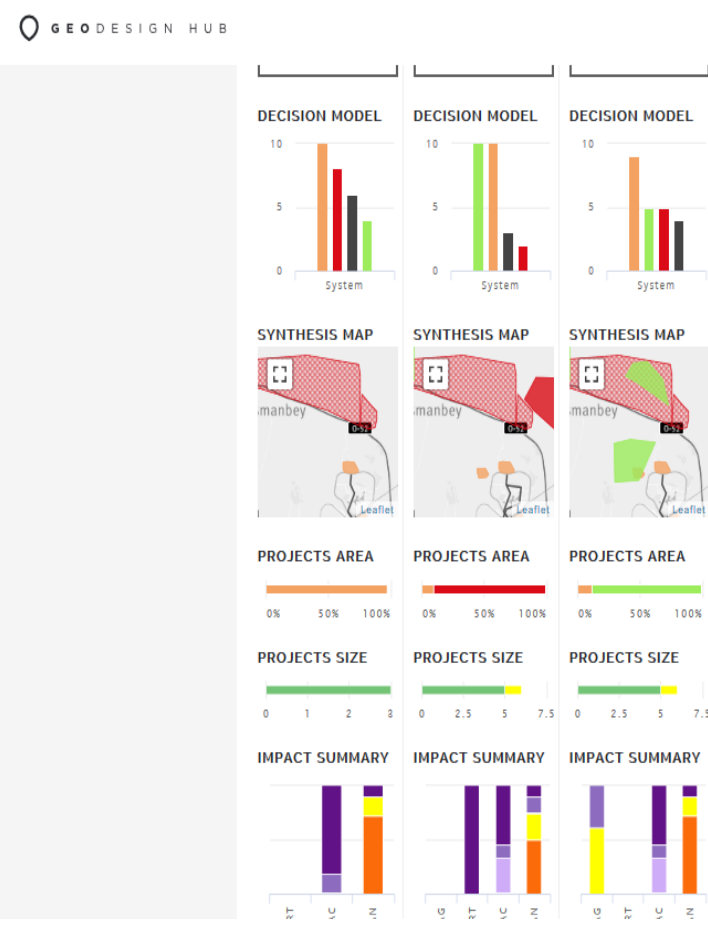

Figure 4. Geodesign Hub showing 3 development scenarios wing based system has been acquired, training conducted and testing carried out.

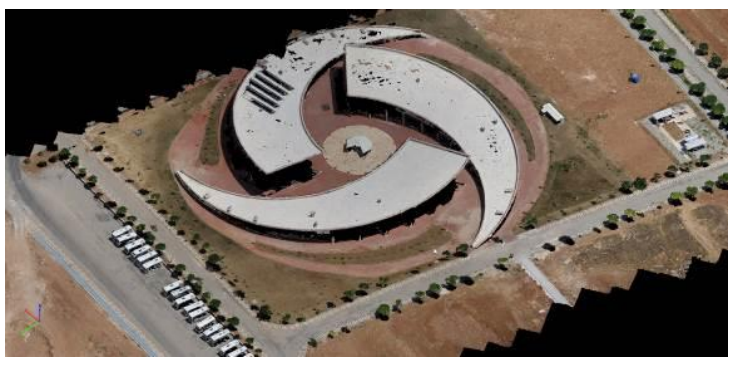

Figure 5. Point cloud of GAP YENEV derived from multi-copter UAS

\section{CONCLUSION}

Harran University decided to create a new master plan for its main campus, Osmanbey, using Geodesign methodology. Using this methodology, the master plan would satisfy three criteria: 1) Creation based on a participatory approach, 2) Development of a user-friendly GUI allowing decion-makers to be actively involved, and 3) Building of a dynamic system that allow the easy integration of future changes. So far, passes 1 (definition of scope) and 2 (definition of exact methodology) according to the Geodesign methodology of Steinitz have been finished. Works for pass 3 (implementation of the methodology) are continuing.

\section{REFERENCES}

McElveney, S., 2012, Geodesign - Case Studies in Regional and Urban Planning, (Redlands: ESRI Press).

Nyerges, T., Ballal, H., Steinitz, C., Canfield, T., Roderick, M., Ritzmann, J., Thanatemaneerat, W., Geodesign dynamics for sustainable urban watershed development. Sustainable Cities and Society 25, pp. 1324.

Steinitz, C. A, 2012, Framework for Geodesign, (Redlands: ESRI Press).

Accordingly, data collection had to be limited to support the evaluation of the above mentioned systems. Among others, the deployment of Unmanned Aerial Systems (UAS) seemed to be necessary in order to collect data with the required accuracy for such a vast area. For collecting data in the already developed area, a multi-copter based and in the bigger undeveloped part of the campus, a fixed 